\title{
Agricultural Research in an Era of Climate Change
}

\author{
M. S. Swaminathan • P. C. Kesavan
}

Received: 21 December 2011/Accepted: 26 December 2011/Published online: 31 January 2012

(C) The Author(s) 2012. This article is published with open access at Springerlink.com

\begin{abstract}
Human-induced changes in climate will have both common and differentiated impacts. It is now widely accepted that the average mean temperature will increase by 1 to $2^{\circ} \mathrm{C}$ during this century. Such an increase in temperature will reduce the duration of crops like wheat and thereby reduce yield in Northern India. In contrast, a rise in mean temperature will increase the crop duration resulting in higher yield in the Northern latitudes. Climate change leading to adverse changes in temperature, precipitation and sea level will disturb the food, water and livelihood security systems in South Asia and Sub-Saharan Africa, regions where already widespread hunger prevails. Pest and disease problems will increase. For example, stem rust of wheat may become important in North India, if the mean temperature goes up. Similarly, the advantage of an aphid-free season for raising disease-free seed potato in the plains of North India will be lost. Recourse will have to be taken to true potato seeds. Anticipatory research to checkmate the adverse impact of unfavourable weather is urgently needed. Crop breeding should shift its emphasis from per crop to per-day productivity. Drought and floods codes will have to be developed and implemented. Climate risk management research and training centres should be established in all agro-climatic zones. Gene Banks containing genetic resources for a warming planet should be set-up. Along coastal areas, mangrove and non-mangrove bioshields should be established. Sea water farming using agri-aqua production systems should be popularised. Genetic Gardens of Halophytes should be established. Salinity tolerant varieties of rice and other crops should be developed using recombinant DNA technology where needed. The poor nations and the poor in all nations wills suffer most from climate change, since they do not have the necessary coping capacity. Agricultural research should therefore be tailored to the need for climate resilient farming systems. Climate literacy should be spread and a cadre of Community Climate Risk Managers should be formed in villages. The calamity of climate change should be converted into an opportunity for developing and spreading climate resilient farming techniques and systems.
\end{abstract}

Keywords Climate change $\cdot$ Agriculture

\section{Introduction}

Climate is the statistical description in terms of means and variability of key weather parameters for a given area over a period of time, usually about 30 years. Today, the commonly used term 'climate change' represents any change in climate over time, whether due to natural causes and/or as a result of human activities. A major reason to implicate

M. S. Swaminathan $(\bowtie) \cdot$ P. C. Kesavan M S Swaminathan Research Foundation, Chennai, India e-mail: swami@mssrf.res.in human or anthropogenic activities for climate change is the fact that these are closely linked with increasing concentrations of carbon dioxide, methane, nitrous oxide and other greenhouse gases known to trap the heat from solar radiation in the upper layers of the Earth's atmosphere. Interestingly, in the same year-1865, when Johann Gregor Mendel announced the laws of heredity, John Tyndall postulated that gases such as water vapour and carbon dioxide in the "atmospheric envelope" trap and retain the heat. In 1896, the Nobel Laureate Svante Arrhenius predicted that increases of atmospheric $\mathrm{CO}_{2}$ from burning fossil fuels would lead to global warming. He had also 
made calculations which suggested that doubling of $\mathrm{CO}_{2}$ concentrations (then about $260 \mathrm{ppm}$ ) in the atmosphere would raise the temperatures of the Earth by about 2 to $6^{\circ} \mathrm{C}$. At present, the $\mathrm{CO}_{2}$ concentration alone is about $398 \mathrm{ppm}$, leaving aside the other greenhouse gases arising largely from anthropogenic causes. The $\mathrm{CO}_{2}$ plus the other heat-trapping gases form what is referred to as " $\mathrm{CO}_{2}$ equivalent", which now is about 470 to $480 \mathrm{ppm}$. All these support the estimate by the Intergovernmental Panel on Climate Change (IPCC) that the Earth will warm by $1.4-5.8^{\circ} \mathrm{C}$ during the current century [6]. Paul Crutzen [3] assigns the term 'Anthropocene' to the present, in many ways human-dominated, geological epoch, supplementing the Holocene-the warm period of the past 10-12 millenia. $\mathrm{He}$ also pointed out that the Anthropocene could be said to have started in the late 18th century, when analyses of air trapped in polar ice showed the beginning of growing global concentrations of $\mathrm{CO}_{2}$ and methane. In this regard, it is of interest to note that the industrial revolution started with the invention of steam engine in 1780 by James Watt. This marked the beginning of a more active phase of human interference in the web of life.

Worldwide, agriculture both contributes to and is threatened by climate change. Agriculture, forestry and fisheries are sensitive to climate change impacts on the one hand, and are also contributing to emissions on the other. Agriculture accounts for $13.5 \%$ of global greenhouse gas (GHG) emissions, or about $1.8 \mathrm{Gt}$ carbon equivalent/year or $6.6 \mathrm{Gt}$ of $\mathrm{CO}_{2}$ equivalent/year, mainly in the form of methane $\left(\mathrm{CH}_{4}\right)$, and nitrous oxide $\left(\mathrm{N}_{2} \mathrm{O}\right)$ from fertilized soils, enteric fermentation, biomass burning, rice production as well as manure and fertilizer production. Land use change and forestry represent $17.4 \%$ of total GHG emissions or 2. GtC equivalent/year (8.4 $\mathrm{Gt} \mathrm{CO}_{2}$ equivalent/ year). In the fisheries sector, $\mathrm{CO}_{2}$ emissions from harvesting and shipping of fish and fish products are estimated at $0.05 \mathrm{Gt}$ per year. It is also estimated that about threefourths of the total emissions from agriculture and land use originate in the developing countries.

Agriculture and forestry also capture a great deal of carbon through photosynthesis, and the precise calculations of the net carbon balance are uncertain. Notwithstanding carbon absorption and fixation through photosynthesis, agriculture and forestry to a much greater extent, and also fisheries to a lesser extent form part of a solution to climate change. These have a very high potential for reducing emissions, and enhancing carbon sinks. The FAO Profile on Climate Change-2009 notes that agriculture has the technical potential to mitigate between 1.5 and $1.6 \mathrm{GtC}$ equivalent/year (5.5-6.0 Gt of $\mathrm{CO}_{2}$ equivalent/year) mainly through soil carbon sequestration in the developing countries. The biophysical mitigation potential of forestry is estimated to average $1.5 \mathrm{GtC}$ equivalent/year $\left(5.4 \mathrm{Gt} \mathrm{CO}_{2}\right.$ equivalent/year). Stern [15] points out that reducing deforestation and forest degradation would be one of the most cost-effective mitigation approaches. According to IPCC [7], forestry and agriculture contribute 17.4 and $13.5 \%$ of total greenhouse gas emissions, respectively. This amounts to nearly $31 \%$. The balance of emissions ( $~ 69 \%)$ comes from energy, industry, transport, buildings, waste and waste water etc. Thus, agriculture, forestry and other land use sectors account for about a third of global anthropogenic GHG emissions. Further, in global terms, livestock contribute to $18 \%$ of the human-generated greenhouse gases. The main greenhouse gases from livestock systems include methane $\left(\mathrm{CH}_{4}\right)$ produced by the belching of animals $(25 \%)$, carbon dioxide $\left(\mathrm{CO}_{2}\right)$ by uses of land that encourage the decomposition of organic substances $(32 \%)$, and nitrous oxide $\left(\mathrm{N}_{2} \mathrm{O}\right)$, produced by spreading manure and slurry over land $(31 \%)$. Improvement of the feed and forage of the ruminant animals in the developing countries to enhance the feed-conversion efficiencies and reduce the amount of methane generated in the production of a unit of milk or meat is the best way of mitigation. Biogas plants will also help. With a large percentage of ruminants $(53 \%$ of the world's buffaloes and $15 \%$ of the world's cattle in the rural sector of India), the need is to develop tropical forages with decreased plant fibre and lignin content, increased content of soluble carbohydrates in roughages, increased content of sulphur amino-acids in the leguminous forages etc. The lignin-rich feed being broken down enzymatically by methane-producing bacteria in the ruminants accounts for nearly 9.0 million tonnes of methane being released annually ( $\sim 9.0 \mathrm{Tg}$ /year). Some studies show that methane produced by the ruminants could be cut by almost $50 \%$ by adding bacteria, Brevibacillus parabrevis as supplement to feed for farm animals. However, the urgent need is to improve the quality of feed and fodder not only to reduce the emission of methane, but also improve milk-yielding capacity of the cows and buffaloes.

\section{Possible Pathways of Mitigation in the Indian Situation}

Agriculture in India is estimated to contribute to $28 \%$ of greenhouse gases. Of this, enteric fermentation in ruminants accounts for about 50\% in the form of methane. Methane emission from rice fields and nitrous oxide from the application of manures and fertilizers is also significant. Nitrification inhibitors and slow release fertilizers like neem-coaled urea will help to mitigate.

Since rice cultivation makes a large contribution to the release of green house gases, the adoption of a system of rice cultivation that does not require huge amounts of water and chemical fertilizers, with a proven track-record of 
much higher yields would be an effective solution. This is referred to as the "System of Rice Intensification" (SRI) which holds good for the most of the cultivated rice varieties. It largely involves radical changes in the agronomic practices. Above all, SRI greatly benefits small and marginal farmers with limited/little resources for chemical inputs such as fertilizers, pesticides etc. Mitigation of methane emission from rice cultivation could also be by altering water management, particularly promoting midseason aeration by short-term drainage; improving organic matter management by promoting aerobic degradation through composting or incorporating it into soil during offseason drained period etc. A site-specific nutrient management (SSNM) is recommended for reducing nitrous oxide emission. In addition, use of nitrification inhibitor such as nitrapyrin and dicyandiamide (DCD) will also help in reducing the emission of nitrous oxide. Application of neem oil and neem cake also reduces the emission by inhibition of nitrification. Reduced tillage and 'no till', residue incorporation, improving soil biodiversity and mulching, enhance sequestration of carbon in the soil.

Swaminathan [20] observed that the largest opportunity for mitigation lies in increasing soil carbon sequestration and thereby building soil carbon banks. Increase in the soil carbon pool in the root zone by 1 ton $\mathrm{C} / \mathrm{ha} / \mathrm{yr}$ will help to increase food production substantially, since one of the major deficiencies in soil health is low soil organic matter content. He has recommended the planting of a billion "fertilizer trees", which can simultaneously sequester carbon and enhance soil nutrient status. The African fertilizer tree, Faidherbia albida, takes nitrogen from the air and fixes it as nitrates in their leaves, which are subsequently incorporated into the soil. It would be useful to establish Genetic Gardens of Fertilizer Trees in different agro-ecosystems.

\section{Impact of Global Warming on Food Security}

During the last ice age, which ended only 14,000 years ago, global surface temperature was $5^{\circ} \mathrm{C}$ lower than it is today. That means it was about $10^{\circ} \mathrm{C}$. The $\mathrm{CO}_{2}$ levels in the atmosphere were much lower (not exactly known but presumably about $200 \mathrm{ppm}$ ). Over a period of about 5,000 years, the global surface temperature gradually rose to an average of about $15^{\circ} \mathrm{C}$, where it remained until about 100 years ago. Then, as a result of human activity, a "thickening" of the blanket of greenhouse gases occurred and the earth's average surface temperature started to increase rapidly. Today, it has risen to about $15.7^{\circ} \mathrm{C}$, or by $0.7^{\circ} \mathrm{C}$ above the pre-industrial levels. The temperature increase is, however, not uniform throughout the planet. The rise of temperature is much higher $\left(\sim 3\right.$ to $\left.4^{\circ} \mathrm{C}\right)$ at the
Polar Regions than at the equatorial regions. Scenarios published by the IPCC predict temperature rises up to $4.5^{\circ} \mathrm{C}$ higher by 2080 , depending on a range of factors and pathways that human development may take. The IPCC envisioned a target that would limit the increase of global temperatures to $2^{\circ} \mathrm{C}$ in comparison to the pre-industrial times in order to prevent climate change from having damaging consequences and negative impacts on people, ecosystems and food systems. Climate change is already contributing to severe droughts, floods and hurricanes, and spreading vector-borne diseases such as malaria, dengue fever etc. Climate change will have both common and differentiated impacts. For example, countries in northern latitudes will benefit from a higher temperature, since the growing season for crops will be longer. In contrast, in Punjab and other part of India, the growing period for wheat will get shorter, thereby reducing yield.

The greatest adverse impact of global warming related to climate change and sea level rise will be on the ecological foundations of agriculture broadly encompassing livelihoods, water security and food production systems. Degradation of soil, fresh water, and biodiversity would affect adversely the sustainability of the production system. Swaminathan [17] has pointed out that biodiversity is the feed stock for a climate resilient agriculture.

To sum up, the detrimental consequences of global warming are multidimensional and interrelated as follows:

- Unpredictable deviations in monsoon behaviour

- Fresh water scarcity and higher evapotranspiration

- Receding glaciers

- More frequent incidence of extreme hydrometeorological events (cylones, hurricanes, typhoons, floods and droughts etc.) with increased destructive potential.

- Emergence of widely different pests causing severe damage to crops, infectious diseases, epidemics etc.

For instance, Indian agriculture normally referred to as a "gamble with monsoon" would become even more to weather behaviour vulnerable. With lesser precipitation and increased evapotranspiration, survival and productivity of agri-horticultural crops would become a serious problem. Several plantation crops like rubber might experience excessive heat at the present altitudes in which they grow. Planting them at higher altitudes will lead to a further destruction of biodiversity. The coastal soil and aquifers would become salinized and staple food crops like paddy would come under severe stress. A rise in sea water temperature will affect mortality of fish and their geographical distribution. Decline in the corals in the Indian Ocean is already reported.

A change in the species and intensities of pests attacking crop plants due to climate change has also been envisioned. There are a few reports that some indigenous pests that 
were earlier not causing much damage are emerging as serious pests such as foliar blight in wheat, necrosis in sunflower, bract mosaic in banana, sheath blight in maize, and paddy, and pyrilla in sugarcane. Stem rust of wheat may become important in North India. Similarly, the advantage of an aphid-free-season will be lost in the case of potato seed production in North India. Farmers will have to adopt the true potato seed (TPS) or tissue culture raised mini-tubers for raising disease-free crops.

At high temperature, the physiological processes in farm animals are also expected to increase resulting in a decline in the productivity of meat, milk, wool, and draught power. There will also be increased incidence of diseases such as mastitis and 'foot and mouth' disease in dairy animals due to rise in temperature and humidity.

With every $1^{\circ} \mathrm{C}$ rise in temperature, yield of rice and wheat will decrease. Scientific studies by Sinha and Swaminathan [21] two decades ago showed that $1^{\circ} \mathrm{C}$ increase in temperature will reduce wheat production by 4 to 5 million tonnes per year. The FAO 2009 (http://en. wikipedia.org/wiki/Climate_change_and_agriculture) also concluded that for each $1^{\circ}$ rise in temperature, wheat yield losses in India are likely to be around 6 million tonnes per year, or around $\$ 1.5$ billion at current prices. There will be similar losses in other crops. Swaminathan [20] pointed out that India's resource poor farmers could lose the equivalent of over $\$ 20$ billion in income each year. The hardship and drudgery on rural women would increase even more steeply since they are traditionally responsible to look after animals, feed, fodder, fuel wood and water.

Swaminathan [22] has urged that anticipatory research should be undertaken to checkmate the adverse impact of a rise in mean temperature. For example, breeders should shift their emphasis from per crop productivity to per-day productivity in order to offset the impact of reduced crop duration.

\section{Understanding Vulnerability of Agriculture}

Vulnerability refers to the ability of a community, group or individual to cope with the impacts of a hazard and to recover. Vulnerability incorporates at least three measures: (i) the degree of exposure to the impacts of climate change, (ii) to what extent one has been affected, directly or indirectly, and adversely or beneficially by the climate change impacts and (iii) the potential to cope with change impacts, recover and adjust. Of these, exposure to the impacts of climate change is a key element of vulnerability. Exposure to climate hazards encompasses both the frequency and severity of a hazard. An example is the recurrent cyclones, floods and drought etc.
Sensitivity to climate change is influenced by level of technology development, culture, tradition, gender, social networks, equity and governance. Social factors also include population size, density, distribution, etc. However, because of their limited coping capacity the poor nations and poor in all nations will be the worst sufferers of climate change.

The hazards associated with climate change arise from 'slow onset' and sudden, extreme events. Sea level rise is an example of slow onset change. The IPCC report (2001) indicated that the global average sea level has risen by 10 to $20 \mathrm{~cm}$ over the past 100 years. This represents a rate of increase of 1 to $2 \mathrm{~mm}$ per year, which is about ten times faster than the rate observed during the previous 3,000 years. It also projected a global average temperature increase of 1.4 to $5.8^{\circ} \mathrm{C}$, and a consequential rise in global mean sea level of $9-88 \mathrm{~cm}$, by the year 2100 . An example of sudden, extreme event is an increase in the frequency and intensity of tropical cyclones. Irrespective of the slow onset or sudden, extreme event, the approaches to mitigate and enhance resilience are largely the same.

\section{Vulnerability of Agriculture (Ecological)}

Swaminathan [22] describes two major types of impacts of climate change on agriculture. First, by altering production adversely in the main food-producing areas, climate change could result in increased food scarcities. The location of main food-producing regions could change. The other impact could be on the physiological mechanisms regulating plant and animal productivity with changes in precipitation patterns causing the maximum adverse impact.

Not all regions of the world contribute equally to food production. The impact of climate change on the major foodproducing regions would affect global food security system significantly. Four major areas need considerations. The first is located in the humid tropics, in lowland areas of Asia and in the Pacific and Caribbean. These areas, normally prone to excessive rains and flooding, may be less severely affected by climate change. The second group, in the arid and semiarid areas of the tropics in Africa and South Asia and in the Mediterranean climate of West Asia and North Africa, will be extremely vulnerable. A third group comprising farmers at high altitudes may experience both favourable and unfavourable effects. The fourth group at the cold margins at higher latitudes may also experience diverse effects. Swaminathan [18] has suggested that overall levels of production can be maintained through a combination of shifts of agricultural zones and adjustments in technology and management. These, however, require an excellent understanding of the varied effects of climate change on soil, water, biodiversity, and physiology of crop plants. 
Some of the adverse effects which need scientific checkmating are the following:

(i) A potentially significant impact to small farm production is loss of soil organic matter due to soil warming; small farms must manage soil nutrients by using farm yard manure, ploughing in stem-nodulating Sesbania rostrata, bio-fertilizers etc. Agro-forestry systems involving fertilizer tree will also help.

(ii) Higher air temperatures are likely to accelerate the natural decomposition of organic matter, which is beneficial,

(iii) Under drier soil conditions, root growth and decomposition of organic matter are significantly suppressed, and as soil cover diminishes, vulnerability to wind erosion increases, especially if wind intensifies. Therefore, rain water harvesting, storage and sustainable use are essential.

(iv) Conditions usually become more favourable for the proliferation of insect pests ad vector-borne diseases in warmer climates. Warmer winter temperatures may also allow larvae to over-winter in areas where they are normally limited by cold, thus causing greater infestation during the following crop season. Migrant pests are expected to respond more quickly to climate change than plants, and may be able to colonise newly available crops/habitats.

(v) Models on plant diseases indicate that climate change could alter stages and rates of development of certain pathogens, modify host resistance, and result in changes in the physiology of host-pathogen interactions. The most likely consequences are shifts in the geographical distribution of pathogens and increased crop losses. The limited literature suggests that the most likely impact of climate change will be felt in three areas: in losses from plant diseases, in the efficacy of disease management strategies, and in the geographical distribution of plant diseases. Climate change could have positive, negative or no impact on individual plant diseases, but with increased temperatures and humidity many pathogens are predicated to increase in severity.

(vi) The above said scenario could necessitate a steep increase in the use of chemical pesticides and this would enhance production costs and also increase the environmental problems associated with agrochemical use. However, within the realm of ever-green agriculture that involves several cereal, pulse, oilseed, vegetable, fodder crops, it is expected that the build up of a particular insect pest species would be greatly retarded. Also, several different crops grown simultaneously enhance the abundance of predators and parasites which provide biological suppression of pest densities. (vii) The increased $\mathrm{CO}_{2}$ concentration in the atmosphere will enhance the photosynthetic efficiency, and the biomass of crop plants, forest trees and other plant species $[5,8,9]$. Increase in the photosynthetic efficiency and biomass production due to increase in $\mathrm{CO}_{2}$ concentration have been shown in important crop plants like rice [2, 26], wheat [25], sorghum [1] and cotton [12].

(viii) The possible adverse effect on biodiversity could be judged from the available evidence that cor $_{a} l s$ in many tropical regions are experiencing substantial mortality from increasing water temperatures, increasing storm intensity, and a reduction in $\mathrm{pH}$.

Anticipatory research should be undertaken to deal with impacts like the above. Proactive action will help to minimize hardship.

\section{Vulnerability of Agriculture (Physiological)}

Normally, increased $\mathrm{CO}_{2}$ in the atmosphere can help to increase the rate of photosynthesis if water and nutrients do not become limiting factors. It should be noted that $\mathrm{C}_{3}$ and $\mathrm{C}_{4}$ plants (i.e., those which have a 3-carbo $n$ or 4-carbon pathway of photosynthesis) respond diff $_{\mathrm{e}}$ rently. The $\mathrm{C}_{3}$ crops like wheat, barley, rice and potatoes could respond positively to $\mathrm{CO}_{2}$ enrichment. However, as has been pointed out by Sinha and Swaminathan [14] the rise in temperature would nullify the benefit of higher $\mathrm{CO}_{2}$ concentration. They examined the integrated impact of a rise in temperature and $\mathrm{CO}_{2}$ concentration on the yield of rice and wheat in India. The study showed that for rice, increasing mean daily temperature decreases the period from transplantation to maturity. Such a reduction in duration results in lower crop yield. There are, however, genotypic differences $i_{n}$ per-day yield potential and there is scope for breeding for per-day productivity.

In wheat, there is an adverse impact on yield if the mean temperatures rise by 1 to $2^{\circ} \mathrm{C}$. For each $0.5^{\circ} \mathrm{C}$ increase in temperature, there would be a reduction of crop duration of seven days, which in turn would reduce yield by 0.45 tonnes per hectare. Also, for an increase of $1{ }^{\circ} \mathrm{C}$ in mean annual temperature, the thermal limit of cereal cropping in mid-latitude northern hemisphere regions would tend to advance by about 150 to $200 \mathrm{~km}$; the altitudinal limit to $\mathrm{a}_{\mathrm{r}}$ able agriculture would rise by about 150-200 m. Several other studies also suggest that for the core mid-latitude cereal regions, an average warming of $2{ }^{\circ} \mathrm{C}$ may decrease potential yields by 3 to $17 \%$.

For India as a whole, rice may become even more important than now in the national food security system, since rice unlike wheat can give high yields under a wider 
range of growing conditions. For example, rice grows under below sea ${ }_{1}$ evel conditions in Kuttanad in Kerala, as well as in high altitude regions in the Himalayas. The amplitude of adaptation is high is rice. This explains why there are nearly 150,000 strains of rice in the world. The Gene Bank at the International Rice Research Institute (IRRI) holds around 107,000 accessions of rice.

In the USA, the U.S. Climate Change Science Program (CCSP) [24] had Commissioned a group of experts to assess the ways that climate change is affecting U.S. Agriculture, land resources, water resources and biodiversity (these are the ecological foundations of sustainable agriculture). The highlights of the Scientific Assessment of the effects of Global Change on the USA are:

(i) Life cycle of grain and oilseed crops will likely progress more rapidly; but with rising temperatures and variable rainfall, crops will begin to experience failure, especially if precipitation lessens or becomes more variable.

(ii) In arid lands, changes in temperature and precipitation will likely decrease the vegetation cover that protects the ground surface from wind and erosion.

(iii) Rising $\mathrm{CO}_{2}$ will very likely increase photosynthesis in forests, but this increase may help to enhance wood production in young forests on fertile soils.

(iv) Increase in the stream temperatures are likely to increase as the climate warms, which will impact aquatic ecosystems both directly and indirectly.

(v) Corals in many tropical regions are experiencing substantial mortality from increasing water temperatures, increasing storm intensity, and a reduction in $\mathrm{pH}$.

In general, higher temperatures are found to result in reduced rice yields in all seasons and in most locations. As mentioned earlier, the possible increase in rice yields because of increased $\mathrm{CO}_{2}$ levels is nullified by a rise in temperature.

Simulations of impact of climate change on wheat yields for several locations in India using a dynamic crop growth model indicated that productivity depended on the magnitude of temperature change. The Indian simulation studies [11] suggested that wheat yields would be smaller than those in the current climate, even with the beneficial effects of $\mathrm{CO}_{2}$ on crop yields, since yield reductions are associated with a shortening of the wheat-growing season resulting from projected temperature increases.

Very little information is available on the physiology and productivity as affected by rise in temperature and $\mathrm{CO}_{2}$ in plantation crops like rubber, oil palm, coconut, sugarcane, coffee, and spices etc. However, studies have been initiated at the Rubber Research Institute of India in Kottayam and preliminary results show that the latex yield will decline with a rise in temperature. While selecting new areas for planting rubber, this factor should be kept in view.
In most developing countries with long coastline and developing small island state countries, climate change related degradation of living aquatic resources would lead to loss of livelihoods, and food insecurity. For instance, with rise in sea surface temperatures, coral decline and death result in loss of fish breeding and harvesting grounds leading to lower fish stocks and catch. Damage to coral reefs and sea grass beds leads to loss of habitat for fish, turtles, and other marine organisms. This leads to smaller fish catch and threatens fisheries based livelihoods.

\section{Mission for Sustainable Agriculture Within the Framework of an Evergreen Revolution}

The major objective of achieving productivity in perpetuity without ecological harm could be adversely affected by the impact of climate change. The climate change factors affecting agriculture are:

- Increase in temperature;

- Changes in precipitation, resulting in drought and floods;

- Widespread run off (leaching of soil nutrients);

- Reduction in fresh water availability;

- Adverse impact on coastal agriculture due to sea water intrusion;

- Outbreak of pests and diseases; and

- Climate refuges seeking new habitation and livelihood locations as a result of a rise in sea level.

The identification of these factors would greatly help in developing appropriate strategies to overcome the negative impact, and maintain reasonably successful sustainable agriculture. The National Action Plan on Climate Change (NAPCC), prepared by the The Prime Minister's Council on Climate Change, Govt. of India, has identified following eight missions:

1. National Solar Mission

2. National Mission for Enhancing Energy Efficiency

3. National Water Mission

4. National Mission for Sustaining the Himalayan ecosystem

5. National Mission for 'Green' India

6. National Mission for sustainable agriculture

7. National Mission for sustainable Habitat

8. National Mission on Strategic knowledge for climate change

Considering the fact that nearly $25 \%$ of India's population live near coastal areas (about $50 \mathrm{~km}$ from the shoreline) there is a need for a National Mission on Integrated Coastal Area Management. Such a Mission should also identify locations where climate refugees from the coast can be resettled. 
The Mission on Sustainable Agriculture recognizes that agriculture contributes only $17 \%$ to GDP, but accounts for $57 \%$ workforce employment. About 600 million people directly or indirectly depend on agriculture for their livelihoods. Further, out of the net cultivated area of about 141 million ha, about 85 million ha $(\sim 60 \%)$ fall under dryland/ rainfed zone. It is therefore appropriate to focus on dryland agriculture. It should be emphasized that in India agriculture is not just a food-producing machine, but is the backbone of the livelihood security system for 700 million men, women and children

The Actions for adaptation involve, among other things, the development of drought-and pest-resistant varieties. At the M S Swaminathan Research Foundation (MSSRF), salinity-caused stress to crop plants has already been given anticipatory attention in view of the fact that with sea level rise along the $7,680 \mathrm{~km}$ long coastline, salinization of land and aquifer would be a very major concern. Genetic shielding of crops against drought-related stress is also receiving major attention. The importance of modern r-DNA technology to evolve salt-and drought tolerant varieties of rice is now widely recognized.

Swaminathan [18] has outlined a strategy for adapting Indian agriculture to climate change. His proposals integrate the use of frontier technologies such as recombinant DNA and Marker assisted selection procedures and information and communication technology, with traditional wisdom. The ecological dimension of establishing bioshields of mangrove and non-mangrove tree/shrub species along the coast to reduce damage to humans, cattle and agricultural fields, and establishing crop-weather watch groups also need attention. Contingency planning based on computer simulation models to meet different weather probabilities (alternative land and water use plans), and monsoon management are also important. The monsoon and the market are two major determinants of farmers' well-being. Dynamic information on these two factors should be conveyed to farm families in local languages at the right time.

Swaminathan [21] in a lecture in Tokyo in 1988 pointed out that a rise in sea level will lead to major consequences such as the following:

(i) loss of arable land due to erosion and submergence and

(ii) progressive salinization of soil and aquifers. The coastal agriculture predominantly with rice as the staple crop is highly vulnerable to salinity. The question is how to sustain rice cultivation and its productivity in view of India's long coastline. Mangroves which have the "genes for salinity tolerance", could be used for the breeding of salinity tolerant rice verities using the recombinant DNA technology. The suggestion made twenty years ago, is already a reality now with the development of salinity tolerant transgenic rice at the MSSRF.

What was done was to identify the genes responsible for conferring "salinity tolerance" in the mangrove species Avicennia marina, isolate them, and transfer these genes through appropriate techniques to the cells in vitro of the rice variety to which the salinity tolerance genes need to be transferred [10]. There are several genes responsible for salinity tolerance in A. marina. The genes so far successfully transferred to rice (Table 1), are being assessed for salinity tolerance under field conditions.

In addition to these technology-based human efforts to genetically shield the coastal agricultural crops against salinity stress, there are also spontaneously occurring crop varieties with salinity tolerance, drought tolerance etc. Halophytes are the gifts of nature-a consequence of spontaneous mutations and natural selection favouring their survival under unfavourable/extreme conditions. These variants should be selected and used as 'donors' of useful genes for genetic shielding of the high yielding improved crop varieties. In fact, the landraces maintained by rural farmer-conservers would have the advantage of crossability and exchange of genes with the locally suited improved (high yielding) rice varieties. Useful segregant (i.e., derivative progenies) from these crosses would be free from the public concerns related to transgenic and readily acceptable for human consumption at home and abroad. Since India is a primary centre of diversity of rice, conserving and widening its agro-biodiversity base with genes for drought, flood, salinity and submergence tolerance would be extremely prudent. MSSRF is establishing a 'Genetic Garden of Halophytes' in Vedaranyam in Tamil Nadu, India.

Irrigation water might become an increasingly limiting factor in agriculture. Using the highly drought resistant plant Prosopis juliflora, the MSSRF scientists are transferring the "drought tolerance genes" from this plant to cultivated rice.

The new genetics has opened up uncommon opportunities for developing novel genetic combinations for sustaining crop production under severe abiotic stresses.

Table 1 Mangrove genes transferred to rice for salinity tolerance

\begin{tabular}{ll}
\hline Genes & $\begin{array}{l}\text { Tolerance } \\
\text { of } \mathrm{NaCl}(\mathrm{mM})\end{array}$ \\
\hline Superoxide dismutase & 150 \\
$\mathrm{Na}+\mathrm{H}+$ Antiporter & 200 \\
Abscorbate peroxidase (Apx) & 150 \\
Glutathione transferase & 150 \\
Monodehydroascorbate reductase & 150
\end{tabular}


Under the SRI approach to manage "dry rice cultivation", the paddy remains wet, but not saturated as in water logging conditions the rice develops a much stronger and deep-penetrating root system, which is more effective in absorbing nitrogen, making for a hardier, more pest-resistant plant. The tillering is more profuse thereby producing more grains per plant. The field trials in Tamil Nadu, Puduchery, Tripura and other places in India have shown that SRI method consumes approximately $40 \%$ less water, and produces about $30 \%$ higher yields. If this method is applied to 20 million hectares of land under rice cultivation in India, the country would produce adequate rice for the country, using "more crops per drop of water" techniques.

\section{Community Management of Climate Change}

The MSSRF has initiated a programme for training Community Climate Risk Managers. The Village Knowledge Centres (VKCs) and Village Resource Centres (VRCs) which provide locale-specific, demand-driven information are rapidly generating and also obtaining weather and crop related data and are providing necessary training and capacity building for the "Community Climate Risk Managers". Such Managers will be familiar with the art and science of managing climate risks like drought, flood, higher temperature and sea level rise. These climate risk managers, will be trained to manage the Good Weather Code, Drought Code, Flood Code etc. The basic procedure is as follows:

Every state should develop a Good Weather Code to maximize the benefits of adequate moisture availability, a Drought Code to minimize the adverse impact of drought, and a Flood Code to prevent excessive distress and damage and to promote a post flood production plan. In the desert areas of Rajasthan, the Good Weather Code should include provision for raising nurseries of appropriate plants, so that in the occasional years when there is excessive rainfall, an extensive tree planting drive can be launched. This will help to strengthen the ecological infrastructure of the desert, and gradually convert the desert into an oasis. "Be prepared" - both to take advantage of a good monsoon and to reduce the impact of adverse seasons-should be our national motto in agriculture.

The Drought Code will help to improve the popularization of crop life saving techniques and the cultivation of low water requiring, but high value crops like pulses and oil seeds. Tuber crops will also do well even if planted somewhat late. The Flood Code should have strategies ready for the post flood farming activities. Seeds and planting material of alternative crops should be built up. After floods, the aquifer will contain adequate water supply and it is important that the post flood season becomes a remunerative cropping season. Crops like yellow flesh Sweet potato will grow well in such areas and will help to strengthen both income and nutrition security.

Global and national policies and strategies will be effective only if they are backed-up by local level thinking and action [16].

The prescription for climate resilient management of agriculture in India elaborated by Swaminathan [21] has the following components:

(i) Conservation farming and climate resilient agriculture in the heartland of green revolution viz., Punjab, Haryana and Western UP in order to defend the gains already made.

(ii) Bridging the gap between potential and actual yields in Eastern India through integrated packages of technology, services and public policies.

(iii) Launching a pulses and oilseeds revolution in rainfed areas through organization of pulses and oilseed villages.

(iv) Launching a post-harvest technology and valueaddition revolution through ending the prevailing mismatch between production and post-harvest technologies and by promoting agro-processing and agribusiness.

(v) Bringing about a management revolution leading to equipping small and marginal farmers with the power and economy of scale.

\section{Conservation of Biodiversity in a Warming Planet}

It is stated [20] that "biodiversity enables the development of plant varieties with novel genetic combinations, which will be required to meet the challenges arising from adverse alterations in temperature, precipitation and, sea level as well as more frequent drought and floods - all of which are anticipated from human-induced climate change". The need for widening the food basket by including under-utilised or "lost" crops was also emphasized. Climate change has underlined the need for increasing our efforts in the area of agro-biodiversity conservation. Swaminathan [17], in his Presidential Address delivered at the International Congress of Genetics in New Delhi in 1983 stressed the need for a conservation continuum, beginning with revitalizing the in situ on-farm conservation traditions of farm families in all countries, and extending up to the establishment of an international genetic resource repository maintained under permafrost conditions. "Although plant conservation on farms and in the wild is the ideal approach to preserving 
genetic diversity in crop plants, these methods are constantly jeopardized by invasive species, human destruction of habitat, and market factors. Therefore, other preservation strategies like ex-situ preservation become essential".

The plea for a permafrost facility to preserve germplasm of crop plants made in 1983 [17] was realized in 2008 in the form of the 'Svalbard Global Seed Vault', set-up by the Norwegian Government, but managed jointly by the Norwegian Ministry of Agriculture, the Global Crop Diversity Trust and the Nordic Genetic Resource Centre. This cryogenic facility is nature-given permafrost. In the middle of an ice mountain in the Norwegian village Longyearbyen on Svalbard Island, a $120 \mathrm{~m}$ tunnel has been chiselled out of a solid stone leading to three vaults that can store sample seeds of 4.5 million varieties. On the first anniversary of this unique Gene Bank that fell on February 26, 2009, Norway organized in Svalbard a seminar on "Frozen Seeds in a Frozen Mountain: Feeding a Warming World" at which Swaminathan delivered a lecture on "Freezing Seeds: A Humanitarian Issue". Such preservation of precious seeds is indeed the next best alternative to their conservation in the fields where evolution and natural selection can continue. After visiting Svalbard Gene Vault, Swaminathan noted, "The remote isolation and capacity of this facility should be sufficient to preserve a sample of the existing genetic variability in all economically important plants, a vast resource generated over the past 10,000 years of agricultural evolution". The Defense Research and Development Organisation (DRDO) of the Government of India have recently set-up a permafrost genetic resources preservation facility at Changla in Ladakh.

Biodiversity is the feedstock for conventional breeding as well as for genetic engineering research. Hence, strengthening in situ conservation and ex-situ preservation by both professionals and farm and tribal families are important.

Open Access This article is distributed under the terms of the Creative Commons Attribution License which permits any use, distribution, and reproduction in any medium, provided the original author(s) and the source are credited.

\section{References}

1. Ainsworth EA, Long SP (2005) What have learned from 15 years of free-air $\mathrm{CO} 2$ enrichment (FACE)? A meta-analytic review of the responses of photosynthesis, canopy properties and plant production to rising CO2. New Phytol 165:351-372

2. Baker JT, Allen LH Jr, Boote KJ, Pickering NB (2000) Direct effects of atmospheric carbon dioxide concentration on whole canopy dark respiration of rice. Glob Change Biol 6:275-286

3. Crutzen PJ (2002) Geology of mankind. Nature 415:23

4. FAO Report (2009) (http://en.wikipedia.org/wiki/Climate_change_ and_agriculture)

5. Idso C, Singer SF (2010) Climate change reconsidered-2009 report of the nongovernmental international panel on climate change (NIPCC), published by The Heartland Institute, Chicago
6. IPCC (2001) Climate changes-2001. IPCC Plenary XVIII, Wembley. www.ipcc.ch/pdf/climate-changes-2001/...spm/synthesisspm-en.pdf. Accessed 24-29 Sept 2001

7. IPCC (2007) Climate change 2007-mitigation of climate change-contribution of working group III to the fourth assessment report of the IPCC, Cambridge

8. Kimball BA, Idso SB, Johnson S, Rillig MC (2007) Seventeen years of carbon dioxide enrichment of sour orange trees: final results. Glob Change Biol 13:2171-2183

9. Lin G, Marino BDV, Wei Y, Adams J, Tubiello F, Berry JA (1998) An experimental and modeling study of responses in ecosystems carbon exchanges to increasing $\mathrm{CO}_{2}$ concentrations using a tropical rainforest mesocosm. Aust J Plant Physiol 25:547-556

10. Parida A, Angela PM, Venkataraman G (2009) Dehydrin gene from Avicennia marina responsible for conferring salt tolerance in plants (US Patent No. 7,622,636 Issued on Nov. 24, 2009)

11. Rao DG, Sinha SK (1994) Impact of climate change on simulated wheat production in India. In: Rosenzweig C, Iglesias A (eds) Implication of climate change for international agriculture: crop modeling study. United States Environment Protection Agency, Washington, DC

12. Reddy KR, Davidonis GH, Johnson AS, Vinyard BT (1999) Temperature regime and carbon dioxide enrichment alter cotton boll development and fiber properties. Agron J 91:851-858

13. Scientific assessment of the effects of global change on USA (2008). http://www.climatescience.gov/Library/scientific-assessment/ Scientific-AssessmentFINAL.pdf

14. Sinha SK, Swaminathan MS (1991) Deforestation, climate change, and sustainable nutrition security. Clim Change 19: 201-209

15. Stern N (2006) Stern review on the economics of climate change. HM Treasury, London

16. Swaminathan MS (1973) Our agricultural future, Sardar Patel Lectures. All India Radio, New Delhi

17. Swaminathan, MS (1983) Genetic conservation: microbes to man. Presidential address to the 15th International congress of genetics. In: Genetics : new frontiers, vol 1. Oxford and IBH Publishing Company, New Delhi, India, 1984

18. Swaminathan MS (2002) From Rio de Janeiro to Johannesburg: action today and not just promises for tomorrow. East West Books (Madras) Pvt. Ltd, Chennai

19. Swaminathan MS (2009) Gene banks for a warming planet. Science 325:517. doi:10.1126/science. 1177070

20. Swaminathan MS (2009) Copenhagen, Tsunami and Hunger, The Hindu, 26th December 2009

21. Swaminathan MS (2010) From green to evergreen revolution, Indian agriculture: performance and challenges. Academic Foundation, New Delhi, p 410

22. Swaminathan MS (2010) Science and sustainable food securityselected papers of M S Swaminathan, IISc Centenary Lecture Series. World Scientific Publishing Co. Pvt. Ltd, p 420

23. Swaminathan MS (2011) Towards an Era of biohappiness: biodiversity and food, health and livelihood security. World Scientific, Chennai, p 170

24. US climate change science program-abrupt climate change (2008) www.climatescience.gov/Library/sap/sap3-4/final-report/

25. Van Ittersum MK, Howden SM, Asseng S (2003) Sensitivity of productivity and deep drainage of wheat cropping systems in a Mediterranean environment to changes in $\mathrm{CO}_{2}$ temperature and precipitation. Agric Ecosyst Environ 97:255-273

26. Weerakoon WMW, Ingram KT, Moss DD (2000) Atmospheric carbon dioxide and fertilizer nitrogen effects on radiation interception by rice. Plant and Soil 220:99-106 